Research Article

\title{
Impact of health education on awareness of HIV/AIDS among school children in rural West Bengal, India
}

\author{
Sulagna Das*, Amiya Das, Aparajita Dasgupta
}

Department of Community Medicine, All India Institute of Hygiene and Public Health, Kolkata, West Bengal, India

Received: 13 August 2016

Accepted: 08 September 2016

\section{*Correspondence:}

Dr. Sulagna Das,

E-mail: drsulagnadas21@gmail.com

Copyright: () the author(s), publisher and licensee Medip Academy. This is an open-access article distributed under the terms of the Creative Commons Attribution Non-Commercial License, which permits unrestricted non-commercial use, distribution, and reproduction in any medium, provided the original work is properly cited.

\section{ABSTRACT}

Background: HIV/AIDS is recognized as a national priority health issue. Inadequate knowledge, negative attitudes and risky practices are major obstacles to prevent the spread of HIV. With the above view the following study was undertaken to assess the level of awareness regarding HIV/AIDS among school children, to raise their awareness through health education program and to determine if the education program would bring about positive change in the knowledge of high school students.

Methods: An interventional study was conducted in a school with all the class IX and X students. A pre-structured questionnaire was used to assess the existing general knowledge on HIV/ AIDS, its mode of transmission, prevention, and some attitude and beliefs. Thereafter educational intervention was done on the same day with the help of power point presentations and black board. One week after the educational intervention, post-test was conducted to know the change in the knowledge.

Results: The study revealed that out of 215 students all of the students had heard about HIV/AIDS but only $53.5 \%$ knew that AIDS is caused by a virus. As regards to mode of transmission only $34.4 \%$ of the students knew about sexual route. There was overall significant change in knowledge $(\mathrm{p}<0.000)$ after educational intervention. Univariable logistic regression analyses indicated that before the intervention the students' level of knowledge about HIV/AIDS was significantly associated with age, grade, father's occupation and mother's educational status but when adjusted with other variables father's occupation lost its significance while the others retained it.

Conclusions: Educational programmes with specific intervention are recommended to increase awareness.

Keywords: Knowledge, HIV/AIDS, Transmission, Intervention

\section{INTRODUCTION}

The acquired immune deficiency syndrome (AIDS) caused by human immunodeficiency virus (HIV) remains the most serious of infectious disease challenges to public health. It has emerged as a global pandemic The United Nations adopted to halt and reverse the spread of HIV/AIDS as one of its millennium development goals. Since the beginning of the epidemic, almost 70 million people have been infected with the HIV virus and about 35 million people have died of AIDS. Globally, 34.0 million (31.4-35.9 million) people were living with HIV at the end of 2011. An estimated $0.8 \%$ of adults aged 1549 years worldwide are living with HIV. ${ }^{1}$

Of all the various age groups affected by this pandemic, Dehne and Riedner identified the adolescent age group as that group that is most at risk of contracting HIV/AIDS and other sexually transmitted diseases (STDs). ${ }^{2}$ Defined by the World Health Organization (WHO) as persons between 10 and 19 years of age, many adolescents around the world are sexually active and many sexual contacts among them are unprotected. ${ }^{3}$ HIV spreads fastest and farthest in conditions of poverty, powerlessness and lack 
of information, the condition in which many young people are frequently exposed to. Adolescents tend to experiment with little awareness of danger. In fact, risky sexual behaviours often are part of a larger pattern of adolescent behaviours (Hoffman and Futterman, 1996).

Most young people have only limited knowledge about HIV/AIDS especially in the rural areas. Young people have been designated as a group at high risk of acquiring HIV/AIDS due to their involvement in sexual experimentation and the use of recreational drugs. Vulnerability of young people to HIV/AIDS can be attributed to physical, social, economical and psychological features of adolescents (Offer,Ostrov, Howard, \& Atkinson, 1988, 270 and Senderowitz, 1995). Socially and economically, most adolescents are dependent and inexperienced, therefore they are unable to protect themselves from infections, and have less access to health care than adults. Again, young people's vulnerability to HIV/AIDS increases as result of cultural practices that shape their behaviors. Adolescence is a stage where young people establish their sexual identities, in doing so they are faced with pressures from society as well as their peers. In India, according to National Family Health Survey-III (NFHS-III), overall 12\% of women aged 15-19 years have become mothers and $4 \%$ of women aged 15-19 years are currently pregnant with their first child. In urban areas, the teenage pregnancy rate is $8.7 \%$ and in rural areas, it is $19.1 \%$. The pregnancy rate among unmarried women aged 15-19 years is reported to be less than $0.05 \%$. Almost $96 \%$ of adolescent girls knew about at least one method of contraception. They are most likely to know about pills. Both urban and rural girls had some level of knowledge in the above aspect. About $78 \%$ knew about pills, $65 \%$ about condoms, and $48 \%$ about intrauterine devices (IUDs) in the age group of 15-19 years. Among unmarried adolescents in the 15-19 year age group reported to have had sexual intercourse. About $17.8 \%$ of them used any method and $14.7 \%$ used modern methods of contraception. Further, $3.0 \%$ of them used pills, $0.2 \%$ used IUDs, and $0.6 \%$ used injectables. ${ }^{4}$

Prevention of HIV/AIDS remains one of the daunting health problems in the world today. With no cure for HIV/AIDS and no effective vaccine available till date, only prevention of transmission of HIV would be effective in significantly slowing the spread of AIDS! The chief approach of prevention of risky behaviour is through health education.

School based educational programmes are an important approach to primary prevention. Newer strategies are evolving every day to keep the scourge at bay. With the above views in mind the following study was undertaken to find out the existing knowledge and change in knowledge about HIV/AIDS after education intervention and to find out the association, if any, between the socio-demographic characteristics and the knowledge, attitude and perception among the study population.

\section{METHODS}

\section{Study design}

An institutional based interventional cross-sectional study

\section{Study setting}

Dearah village was randomly selected from all villages under Dearah subcentre, under Singur RHUTC, the urban field area of All India Institute of Hygiene and Public Health.

\section{Study population}

All the students from classes IX and X present on the day of the study were included in the study. A total of 215 students [131; class IX, (68 boys and 63 girls) and 84; class X, (35 boys and 49 girls)] were present.

\section{Sampling design}

Only co-education schools under Dearah village were enlisted. There were only two such schools, one at Mollah Simla and other at Gobindapur. Gobindapur was randomly selected. The study was thereafter carried out in Gobindapur Purnachandra Vidyayatan, an upgraded secondary school at Gobindapur, Dearah which was established in 1974.

\section{Study period}

September 2013

\section{Study tool and study technique}

A pre-tested self-administered anonymous questionnaire was then used to collect data. The questionnaire was developed in English and then translated into Bengali, the local language. For using it in Bengali vernacular, at first, one forward and one backward translations were done parallel by one medical and one language expert so that the meaning, content and grammatical correctness of the items remained unaltered. For the data collection Bengali version was used. Internal consistency was assessed using Cronbach's alpha, it was 0.89 . Therefore all efforts were made to maintain semantic equivalence and unambiguousness in the final questionnaire. Its content and face validity was ensured with the help of the experts of the Department of PSM, AIIHPH, Kolkata.

The questionnaire which was divided into two parts.

Part I: To gather information about the sociodemographic characteristics of the study population.

Part II: Divided into 4 domains- i. General knowledge about HIV/AIDS ii. Knowledge about the modes of transmission of HIV/AIDS iii. Knowledge about the modes of prevention of HIV/AIDS iv. Knowledge about the attitude and beliefs regarding HIV/AIDS. 


\section{Knowledge scores}

To assess the overall knowledge of HIV/AIDS of the participants a uniform scoring system was adopted which was validated by three public health experts. Each question was closed and one of the pre fixed responses [Yes/No/Do not Know] was the answer: "Correct" response $=2$, "Incorrect" response $=0$, "Don't know"/ "Neutral"= 1. Total nine questions were used to assess the general knowledge of the participants, eleven questions on knowledge about the modes of transmission and seven questions on knowledge about the modes of prevention. All scores were added and the median score calculated. Respondents who scored below and equal to the median value were categorized as having "poor knowledge" while those who scored above the median value were categorized as having "good knowledge". The intervention was a one-class education program about HIV/AIDS for participants which were done on the same day. It was provided to all the students through powerpoint presentation. The power point presentation was given by the researcher herself with the help of three other researchers. The presentation was of one hour duration and included information regarding the source of HIV infection, modes of transmission, high risk groups, complications of the disease, social stigma associated with the disease, various myths, modes of prevention, control, prognosis of the disease, diagnosis and treatment modalities/options under the guidelines of the national programme, the facilities where these services are available and the importance of voluntary HIV testing at ICTC centers. At the end they were also told about the need to include HIV education in the school curriculum and how youngsters like them can prove themselves effective channels for dissemination of awareness regarding the disease. It was also accompanied by a group discussion in which we tried to solve the queries and doubts of the students. One week after the educational intervention, post test was conducted using the same set of questionnaire and the change in the level of awareness was assessed. Post test questionnaire had an additional set of questions as feed-back report.

\section{Data analysis}

The dependent variable was "good knowledge" and "poor knowledge" scores. The independent variables were class/ grade, sex, age, father's educational status, mother's educational status, type of house, father's occupation and mother's occupation. Data was collated manually, checked for errors and entered into the computer. Computer software Statistical Package for Social sciences (SPSS) version 20 was used for the analysis.

\section{Ethical considerations}

Ethical considerations were carefully and systematically adhered to before, during and after the study. Permission to carry out the research was obtained from the officer-in -charge Singur RHUTC, followed by the district inspector and finally from the school headmaster. School students were enrolled after obtaining written consent and participation was purely voluntary and they were also assured that the study will not have any detrimental effect on the participants. The students were assured that any information, thus obtained will be treated with utmost confidence.

\section{RESULTS}

Table 1: Socio-demographic profile of the study population $(n=215)$.

\begin{tabular}{|c|c|c|c|}
\hline Particulars & $\begin{array}{l}\text { Total } \\
\text { Population }\end{array}$ & $\begin{array}{l}\text { Class IX } \\
(n=131)\end{array}$ & $\begin{array}{l}\text { Class } \mathbf{X} \\
(\mathbf{n}=\mathbf{8 4})\end{array}$ \\
\hline \multicolumn{4}{|l|}{ Age } \\
\hline$\leq 14$ & $136(63.3)$ & $105(77.2)$ & $31(22.8)$ \\
\hline$>14$ & $79(36.7)$ & $26(32.9)$ & $53(67.1)$ \\
\hline \multicolumn{4}{|l|}{ Gender } \\
\hline Male & $103(47.9)$ & $68(66.1)$ & $35(33.9)$ \\
\hline Female & $112(52.1)$ & $63(56.2)$ & $49(43.8)$ \\
\hline \multicolumn{4}{|l|}{ Religion } \\
\hline Hindu & $208(96.7)$ & $125(60.1)$ & $83(39.9)$ \\
\hline Muslim & $5(2.3)$ & $4(80)$ & $1(20)$ \\
\hline Christian & $2(0.9)$ & $2(100)$ & 0 \\
\hline \multicolumn{4}{|l|}{ Caste } \\
\hline General & $157(73.0)$ & $97(61.8)$ & $60(38.2)$ \\
\hline $\mathrm{SC} / \mathrm{ST}$ & $54(25.1)$ & $33(61.2)$ & $21(38.8)$ \\
\hline $\mathrm{OBC}$ & $4(1.9)$ & $1(25.0)$ & $3(75.0)$ \\
\hline \multicolumn{4}{|c|}{ Type of house } \\
\hline Kuccha & $24(11.2)$ & $13(54.2)$ & $11(45.8)$ \\
\hline Puccha & $64(29.8)$ & $36(56.2)$ & $28(43.8)$ \\
\hline Mixed & $127(59.1)$ & $82(64.6)$ & $45(35.4)$ \\
\hline \multicolumn{4}{|c|}{ *Father's occupation } \\
\hline $\begin{array}{l}\text { Skilled } \\
\text { workers }\end{array}$ & $153(71.2)$ & $92(60.1)$ & $58(39.9)$ \\
\hline $\begin{array}{l}\text { Unskilled } \\
\text { workers }\end{array}$ & $59(27.4)$ & $37(62.7)$ & $25(37.3)$ \\
\hline \multicolumn{4}{|c|}{ Father's education } \\
\hline$\leq$ Class IV & $113(52.6)$ & $73(64.6)$ & $40(35.4)$ \\
\hline$>$ Class IV & $102(47.4)$ & $58(56.7)$ & $44(43.3)$ \\
\hline \multicolumn{4}{|c|}{ Mother's education } \\
\hline$\leq$ Class VII & $115(53.5)$ & $70(60.1)$ & $45(39.9)$ \\
\hline$>$ Class VII & $100(46.5)$ & $61(61.0)$ & $39(39.0)$ \\
\hline
\end{tabular}

*Fathers of 2 students of Class IX [n=129] and 1 of Class X $[n=83]$ had expired.

Table 1 explains that in the present study, majority of the students $(63.3 \%)$ belonged to the age group of $\leq 14$ years. The mean age was $14.3 \pm 0.98$ years. With a minimum age of 12 years and maximium age of 18 years. Most of them (52\%) were females. $96.7 \%$ were Hindus and $73 \%$ belonged to general caste. Most of the parents of the participants' finished primary level $(47.4 \%$ fathers \& $53.5 \%$ mothers). Most of the fathers were skilled workers $(71.2 \%)$ and mothers housewives (95.8\%).With regard to the sources of information about HIV/AIDS, 34.4\% of the students mentioned that their teachers were the main 
source of information to them. This finding suggests that AIDS education programmes should be strengthened further in schools. Apart from teachers, friends, television and their reading books were also important sources and presented the same in Figure 1.

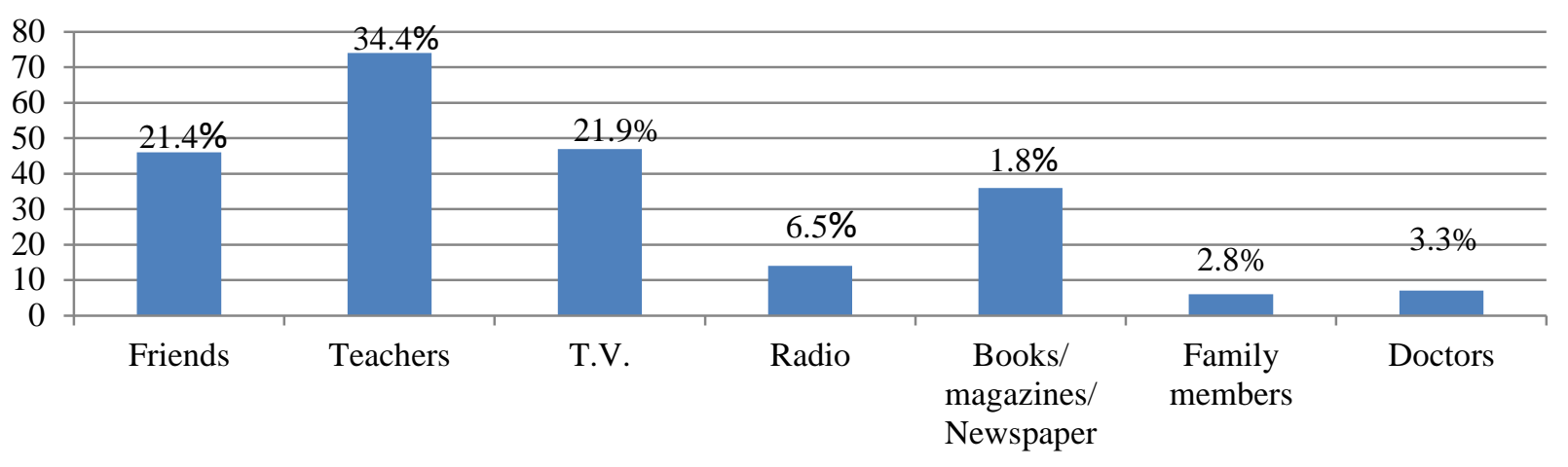

Figure 1: Bar diagram showing the sources of information of knowledge.

Table 2: Frequency distribution of the responses.

\begin{tabular}{|c|c|c|c|}
\hline Domains & Yes $(\mathbf{N} \%)$ & No $(\mathbf{N} \%)$ & Don't know (N\%) \\
\hline \multicolumn{4}{|l|}{ I. General Knowledge } \\
\hline 1. Have you heard about HIV/AIDS? & $215(100)$ & - & - \\
\hline 2. AIDS is caused by a virus & $115(53.5)$ & $26(12.1)$ & $74(34.4)$ \\
\hline 3. Can anyone die from HIV/AIDS? & $106(49.3)$ & $13(6.0)$ & $96(44.7)$ \\
\hline 4. Can anyone infected with HIV/AIDS look healthy? & $30(13.9)$ & $82(38.1)$ & $103(47.9)$ \\
\hline $\begin{array}{l}\text { 5. Do you think that a person who has HIV/AIDS can be } \\
\text { cured? }\end{array}$ & $32(14.9)$ & $69(32.1)$ & $114(53.0)$ \\
\hline $\begin{array}{l}\text { 6. Do we have any medicine that can cure a HIV/AIDS } \\
\text { patient? }\end{array}$ & $35(16.3)$ & $58(270)$ & $122(56.7)$ \\
\hline 7. Have you ever heard of or seen a condom? & $74(34.4)$ & $4.9(22.8)$ & $92(42.8)$ \\
\hline \multicolumn{4}{|c|}{ *8. Are you aware of any facility in your area where you can get tested for HIV/AIDS? } \\
\hline \multicolumn{4}{|c|}{$\begin{array}{l}\text { *9. Have you ever heard of ICTC? (Integrated Counseling and Testing Centre - where one can get information on } \\
\text { HIV/AIDS and get tested for HIV/AIDS) (* Questions not included in analysis) }\end{array}$} \\
\hline \multicolumn{4}{|l|}{ II. Knowledge on modes of transmission } \\
\hline $\begin{array}{l}\text { 1. Can people protect themselves from HIV/AIDS by } \\
\text { abstaining from sexual intercourse? }\end{array}$ & $74(34.4)$ & $49(22.8)$ & $92(42.8)$ \\
\hline 2. Can polygamy transmit AIDS? & $122(56.7)$ & $18(18.4)$ & $75(34.9)$ \\
\hline $\begin{array}{l}\text { 3. Can sharing food, etc., with someone who has HIV or the } \\
\text { AIDS virus transmit AIDS? }\end{array}$ & $39(18.1)$ & $86(40.0)$ & $90(41.9)$ \\
\hline 4. Can it be transmitted through mosquito bites? & $39(18.1)$ & $98(45.6)$ & $78(36.3)$ \\
\hline $\begin{array}{l}\text { 5. Can using a needle or syringe that has been used by a } \\
\text { person with AIDS transmit AIDS? }\end{array}$ & $118(54.9)$ & $29(13.5)$ & $68(31.6)$ \\
\hline 6. Can using a public toilet transmit AIDS? & $48(22.3)$ & $66(30.7)$ & $101(47.0)$ \\
\hline $\begin{array}{l}\text { 7. Do you think untested blood transfusion can transmit } \\
\text { AIDS? }\end{array}$ & $110(51.2)$ & $25(11.6)$ & $80(37.2)$ \\
\hline $\begin{array}{l}\text { 8. Can HIV be transmitted from a pregnant mother to her } \\
\text { unborn child? }\end{array}$ & $104(48.4)$ & $23(10.7)$ & $88(40.9)$ \\
\hline $\begin{array}{l}\text { 9. Can a woman with HIV/AIDS transmit virus to her } \\
\text { newborn child through breast feeding? }\end{array}$ & $92(42.8)$ & $22(10.2)$ & $101(47.0)$ \\
\hline 10. Can HIV be transmitted by air? & $18(8.4)$ & $102(47.4)$ & $95(44.2)$ \\
\hline $\begin{array}{l}\text { 11. Can shaking hands with an infected person transmit } \\
\text { AIDS? }\end{array}$ & $11(5.1)$ & $91(42.3)$ & $113(52.6)$ \\
\hline \multicolumn{4}{|l|}{ III. Knowledge on modes of prevention } \\
\hline 1. Can use of condoms reduce the risk of HIV/AIDS? & $74(34.4)$ & $32(14.9)$ & $109(50.7)$ \\
\hline
\end{tabular}




\begin{tabular}{|llll|}
\hline $\begin{array}{l}\text { 2. Can avoiding sex with commercial sex workers reduce } \\
\text { the chances of transmission? }\end{array}$ & $77(35.8)$ & $24(11.2)$ & $114(53.0)$ \\
\hline $\begin{array}{l}\text { 3. Can avoiding the use of illegal drugs intravenously } \\
\text { reduce the risk of HIV/AIDS? }\end{array}$ & $31(14.4)$ & $69(32.1)$ & $115(53.5)$ \\
\hline $\begin{array}{l}\text { 4. Can the use of unsterilized needles reduce the risk of } \\
\text { transmission? }\end{array}$ & $65(30.2)$ & $66(30.7)$ & $84(39.1)$ \\
\hline $\begin{array}{l}\text { 5. Can sharing of razors/blades or any sharp objects prevent } \\
\text { the transmission of AIDS? }\end{array}$ & $55(25.6)$ & $75(34.9)$ & $85(39.5)$ \\
\hline \begin{tabular}{l} 
6. Is there a vaccine against AIDS? \\
\hline 7. Is there any antibiotics to prevent AIDS?
\end{tabular} & $53(24.7)$ & $44(20.5)$ & $118(54.9)$ \\
\hline IV. Attitude and belief towards HIV/AIDS & Agree (N \%) & Neutral (N\%) & Disagree (N \%) \\
\hline $\begin{array}{l}\text { 1. Community should allow HIV/AIDS patients to stay in } \\
\text { the village/ locality }\end{array}$ & $83(38.6)$ & $79(36.7)$ & $53(24.7)$ \\
\hline $\begin{array}{l}\text { 2. People infected with HIV should be ashamed of } \\
\text { themselves }\end{array}$ & $65(30.2)$ & $51(23.7)$ & $99(46.1)$ \\
\hline $\begin{array}{l}\text { 3. Sexual intercourse should take place only between } \\
\text { married couples }\end{array}$ & $95(44.2)$ & $54(25.1)$ & $66(30.7)$ \\
\hline $\begin{array}{l}\text { 4. In case any member of your family suffers from } \\
\text { HIV/AIDS he/she will be isolated in the family }\end{array}$ & $27(12.6)$ & $61(28.4)$ & $127(59.1)$ \\
\hline $\begin{array}{l}\text { 5. You would not be afraid of visiting a friend sick with } \\
\text { AIDS }\end{array}$ & $46(21.4)$ & $75(34.9)$ & $94(43.7)$ \\
\hline 6. HIV positive patients should not be given a job & $28(13.0)$ & $69(32.1)$ & $118(54.9)$ \\
\hline $\begin{array}{l}\text { 7. Adolescents should be taught how to protect themselves } \\
\text { from HIV/AIDS }\end{array}$ & $141(65.6)$ & $38(17.7)$ & $36(16.7)$ \\
\hline
\end{tabular}

Table 3: Change in knowledge scores.

\begin{tabular}{|c|c|c|c|c|c|c|}
\hline $\begin{array}{l}\text { Phases of } \\
\text { testing }\end{array}$ & Mean (SD) & $\begin{array}{l}\text { Maximum } \\
\text { attained score }\end{array}$ & $\begin{array}{l}\text { Minimum } \\
\text { attained score }\end{array}$ & Median & $\begin{array}{l}\text { t- test value } \\
\text { (df) }\end{array}$ & Sig (2tailed) \\
\hline $\begin{array}{l}\text { Total post } \\
\text { score }\end{array}$ & $54.42(4.81)$ & 64 & 40 & 55 & \multirow{2}{*}{$52.22(214)$} & \multirow{2}{*}{0.000} \\
\hline $\begin{array}{l}\text { Total pre- } \\
\text { score }\end{array}$ & $20.17(10.16)$ & 48 & 2 & 23 & & \\
\hline
\end{tabular}

Table 4: Association between sociodemographic characteristics and knowledge scores.

\begin{tabular}{|lll|}
\hline Sociodemographic Characteristics & OR $(\mathrm{CI})$ & AOR*(CI) \\
\hline Age $>14$ & $2.463(1.392-4.359)$ & $1.42(1.30-3.09)$ \\
\hline Sex (female ) & $1.231(0.720-2.103)$ & $1.06(0.54-2.06)$ \\
\hline Class X & $9.297(4.850-17.824)$ & $10.54(4.90-22.66)$ \\
\hline Father's occupation (unskilled worker ) & $0.680(0.471-0.982)$ & $1.31(0.64-2.70)$ \\
\hline Mother's occupation (other than homemakers) & $3.783(0.768-18.644)$ & $3.01(0.49-18.51)$ \\
\hline Father's education (> class IV) & $1.005(0.937-1.077)$ & $0.54(0.27-1.08)$ \\
\hline Mother's education (> class VII) & $1.341(1.259-2.300)$ & $1.08(1.01-1.16)$ \\
\hline
\end{tabular}

Table 2 illustrates the frequency distribution of the different domains. As far the "general knowledge of HIV/ AIDS" is concerned, all (100\%) of the students had heard about HIV/AIDS but only $53.5 \%$ knew that AIDS is caused by a virus. However only $32 \%$ knew that AIDS is not curable at present and dismally only $16 \%$ knew that medicines are available for the treatment. None of the students were aware of VCTC/ICTC. The domain on "knowledge on modes of transmission" shows that only $34.4 \%$ of the students knew about sexual route while $54.9 \%$ named sharing of syringes and needles as a mode of transmission. $51.2 \%$ knew about untested blood transfusion an important mode of transmission. In this study gaps were seen in the awareness about other modes of transmission wherein only $48.4 \%$ and $42.9 \%$ cited mother to child transmission and breast feeding as routes of transmission, respectively. However, the participants had several misconceptions about the non-transmission ways, namely "mosquito bites can cause AIDS", "it can be transmitted by air" and "shaking hands with infected person can transmit AIDS" which persists among 45.6\%, $47.4 \%$ and $42.3 \%$ of students respectively. "Knowledge on the modes of prevention of HIV/AIDS" was very unsatisfactory. Only 34.4\% knew about condoms being 
one of the preventive modes, $25.6 \%$ knew that sharing of razors and blades is harmful and that unsterilised needles should not be used is known to only $30.2 \%$ of the population. As far as "attitude and belief towards HIV/AIDS" is concerned, only $38.6 \%$ of the population believed that "community should allow HIV/AIDS patients to stay in the village/ locality", 59.1\% disagreed to the fact that if "any member of your family suffers from HIV/AIDS he/she will be isolated in the family". Only $43.7 \%$ of the study population thought that one "would not be afraid of visiting a friend sick with AIDS". Dismally $13 \%$ of the population agreed "HIV positive patients should not be given a job". Almost 70\% of them supported the fact that "adolescents should be taught how to protect themselves from HIV/AIDS".

Table 3 demonstrates that paired t- test was carried out to assess the statistical significance and compare the pre and post-test knowledge score. There was a statistically significant improvement in knowledge scores following the awareness programme from $20.17 \pm 10.16$ units to $54.42 \pm 4.81$ units ( $\mathrm{p}<0.000)$; an improvement by $34.25 \pm 9.61$ units.

Table 4 explains univariable logistic regression analyses indicated that before the intervention the students' level of knowledge about HIV/AIDS was significantly associated with age, grade, father's occupation and mother's educational status but when all these variables were put into multivariable logistic regression, father's occupation lost its significance while the others retained it.

\section{DISCUSSION}

Awareness is the key to prevention of HIV/AIDS. The present study showed that all the students in the study population from rural areas of the West Bengal, India had heard about HIV/AIDS. According to the National Family Health, $64.8 \%$ of rural adolescents had heard of HIV/AIDS at the country level. ${ }^{4}$ Our findings reveal a much better result. In the present study, out of 215 students $112(52 \%)$ were girls and the rest were boys. The mean age of the students was $14.3 \pm 0.98$ years and ranged from 12 to 18 years. In a study conducted in South Delhi, the mean age of the responding students was 16.38 years $(\mathrm{SD}=0.945)$ and ranged from 14 to 19 years. $^{5}$ Most of the students $(n=176 ; 70 \%)$ identified themselves as Hindu. Another study in Delhi revealed majority of the students $(74.9 \%)$ belonged to the age group of $15-17$ years. The mean age was $15.8 \pm 0.8$ years. Most of them $(60 \%)$ were females. ${ }^{6}$ These findings were also comparable to the observations of a study carried out amongst the secondary school students in Haryana and Jamnagar. ${ }^{7,8}$ With regard to the sources of information about HIV/AIDS, $34.4 \%$ of the students mentioned that their teachers were the main source of information to them. In the study conducted in Delhi $79.6 \%$ of the students mentioned that television and radio were the main sources of information to them. Likewise, a majority $(62.7 \%)$ of senior secondary students belonging to a government school in Chandigarh reported that they derived most of the information from TV and radio. ${ }^{9} \mathrm{~A}$ study conducted in Gujarat showed the main sources of information regarding HIV/AIDS were friends (77.39\%) and television (69.28\%). ${ }^{10}$ Apart from promoting school based AIDS education programmes these findings imply that television should be promoted as a significant source of information. A greater involvement of print media can also be a cost-effective measure. Awareness about the different methods of prevention was rather low. Only $34.4 \%$ knew about condoms being one of the preventive modes. This finding was higher as compared to $14.9 \%$ which was the finding of Delhi study but it was quite low as compared to another study which showed $69.67 \%$ knew the role of condoms in preventing HIV; $84.58 \%$ knew the role of blood safety; and $82.75 \%$ understood the importance of safe injection practices. ${ }^{6,10}$ Misconceptions regarding the transmission of HIV were noted in the study subjects. Several non-transmission ways, namely "mosquito bites can cause AIDS", "it can be transmitted by air" and "shaking hands with infected person can transmit AIDS" persists among 45.6\%, 47.4\% and 42.3\% of students respectively in the present study. In another study $20.78 \%$ thought that HIV can be transmitted by living with an HIV-infected person; $17.25 \%$ thought that HIV can be acquired through eating food with HIV positive individuals; $18.56 \%$ thought that HIV could be transmitted by a mosquito bite. ${ }^{10}$ In the present study, only $34.4 \%$ of the students knew about sexual route, $54.9 \%$ named sharing of syringes and needles as a mode of transmission wherein only $48.4 \%$ and $42.9 \%$ cited mother to child transmission and breast feeding as routes of transmission, respectively. This finding was not consistent with the study conducted in Gujarat which showed $92.42 \%$ knew that the disease was transmitted through sexual intercourse, $91.11 \%$ knew about transmission through blood transfusion, $87.84 \%$ knew about transmission through the sharing of needles/syringes, and about $83.66 \%$ knew about transmission of HIV from mother to child. ${ }^{10}$ The study conducted in Delhi among secondary school children showed $48.2 \%$ of the students could name sexual route while $44.4 \%$ named sharing of syringes and needles as a mode of transmission. ${ }^{6}$ Similar findings were observed in a study done amongst 2400 secondary school students from Mumbai, in which only $50 \%$ of students knew about the sexual route of transmission. In our study, gaps were seen in the awareness about other modes of transmission wherein only $31.1 \%$ and $23.4 \%$ cited blood transfusion and mother to baby transmission as routes of transmission, respectively. Low levels of knowledge about general aspects and transmission of HIV/AIDS have also been observed amongst secondary school students in Kolkata. ${ }^{11}$

In our study, a majority of the students had a favourable attitude towards people living with HIV/AIDS (PLWHA), stating that such patients should be given a job, if any member of the family suffers from HIV/AIDS 
he/she should not be isolated in the family, people infected with HIV should not be ashamed of themselves and community should allow HIV/AIDS patients to stay in the village/locality. These findings were similar to the study conducted in Delhi.

However, this favourable attitude towards HIV positive patients was not observed among college students in Nashik. $^{6,12}$ Univariate logistic regression analyses indicated that before the intervention the students' level of knowledge about HIV/AIDS was significantly associated with age, grade, father's occupation and mother's educational status but when all these variables were put into multivariable logistic regression, father's occupation lost its significance while the others retained it. A study conducted in China found significant association with grade income status. ${ }^{13}$

\section{Limitations}

Firstly, this study is restricted to a single school and did not include out-of-school adolescents. This limits the generalizability of the study findings to all adolescents of similar age. Second, whilst HIV knowledge is important, it may not be the primary factor in explaining HIV transmission among young people. Many people have adequate knowledge about HIV but do not act on it due to a wide variety of social, cultural and economic constraints.

Future studies that investigate of all these possible constraints could help to improve our understanding of HIV transmission. Third, a three-point scale was used to assess attitudes which may not reflect respondents' views with adequate precision. A five-point scale is usually a better choice in this case. However, fearing the ability of the school students to think in such wider scale, a fivepoint scale was not used. Finally, because of the selfadministered questionnaire, social desirability bias may have occurred. However, the anonymity of the questionnaires hopefully encouraged students to be honest in their responses. Despite all of these limitations, this study might be a reasonable source of information for researchers and policymakers.

\section{CONCLUSION}

To conclude, this study suggests that educational programs on HIV/AIDS prevention are effective and beneficial to secondary school students. HIV/AIDS education will be more successful if education is carried out using continuous and long-term strategies with realistic objectives. Decision-makers as well as school headmasters and teachers should realize that school education is an effective solution to prevent the spread of the HIV/AIDS epidemic. Relevant curricula should be developed every semester and topics in middle school should be different from those in high school depending on the knowledge structures and the perception abilities of the students.

\section{Recommendations}

Provision of free/affordable HIV counselling and screening test centres in or near secondary school campuses can help to de-stigmatise the concept of HIV/AIDS. Inclusion of sex education in secondary school curriculum is the need of the hour. While the teacher plays a pivotal role in imparting education, the use of multi-pronged methods such as films, group discussions, dramas, puppet shows and role-plays must be incorporated. There is a strong need that school education must directly address stigmatizing attitudes about HIV/AIDS, gaps in HIV/AIDS knowledge and awareness of HIV-related health resources.

\section{ACKNOWLEDGEMENTS}

Authors would like to thank Headmaster, Gobindapur Purnachandra Vidyayatan, all students of the school, officer in charge, Singur RHTC, Hooghly, HOD, Department of PSM, All India Institute of Hygiene and Public Health, Kolkata.

Funding: No funding sources

Conflict of interest: None declared

Ethical approval: The study was approved by the Institutional Ethics Committee

\section{REFERENCES}

1. UNAIDS Report on the Global AIDS epidemic UNAIDS, Geneva; 2012

2. UNAIDS. Impact of HIV and Sexual Health Education on the Sexual Behaviour of Young People: A Review Update. UNAIDS, Geneva. 1997.

3. World health organization. The reproductive health of adolescence, strategy for action. A joint WHO/UNFA/UNFPA/UNICEF Statement. WHO, Geneva. 1989: 1.

4. National family health survey. NFHS-III 2005-06. Ministry of health and family welfare. Government of India. Available from: http://www.mohfw.nic.in. Accessed on 25 February 2016.

5. McManus A, Dhar L. Study of knowledge, perception and attitude of adolescent girls towards STIs/HIV, safer sex and sex education: (A cross sectional survey of urban adolescent school girls in South Delhi, India). BMC Women's Health. 2008;8:12.

6. Lal P, Nath A, Badhan S, Ingle GK. A study of awareness about HIV/AIDS among senior secondary school children of Delhi. Indian $\mathbf{J}$ Community Med. 2008;33:190-2.

7. Aggarwal AK, Kumar R. AIDS awareness among school children in Haryana. Indian J Public Health. 1996;40:38-45.

8. Bhalla S, Chandwani H, Singh D, Somasundaram C, Rasania SK, Singh S. Knowledge about HIV/AIDS among senior secondary school students in 
Jamnagar, Gujarat. Health Popul Perspect Issues. 2005;28:178-883.

9. Sodhi S, Mehta S. Level of Awareness about AIDS: a comparative study of girls of two senior secondary schools of Chandigarh. Man India. 1997;77:259-66.

10. Yadav SB, Makwana NR, Vadera BN, Dhaduk KM, Gandha KM. Awareness on HIV/AIDS among rural youth in India: A community based cross sectional study. J Infect Dev Ctries. 2011;5(10):711-6.

11. Chatterjee C, Baur B, Ram R, Dhar G, Sandhukhan S, Dan A. A study on awareness of AIDS among school students and teachers of higher secondary schools in north Calcutta. Indian J Public Health. 2001;45:27-30.
12. Ganguli SK, Rekha PP, Gupte N, Charan UA. AIDS awareness among undergraduate students, Maharashtra. Indian J Public Health. 2002;46:8-12.

13. Gao X, Wu Y, Zhang Y, Zhang N, Tang J, Qiu J, et al. Effectiveness of School-based Education on HIV/AIDS Knowledge, Attitude, and Behavior among Secondary School Students in Wuhan, China. PLoS One. 2012;7(9):44881.

Cite this article as: Das S, Das A, Dasgupta A. Impact of health education on awareness of HIV/AIDS among school children in rural West Bengal, India. Int J Community Med Public Health 2016;3:2932-9. 